\author{
KARolina StojCZEW \\ Uniwersytet Ekonomiczny we Wrocławiu, Polska \\ Wroclaw University of Economics and Business, Poland
}

\title{
Ocena wpływu pandemii COVID-19 na sytuację w branży motoryzacyinej w Polsce
}

\section{Assessment of the impact of the coronavirus COVID-19 pandemic on the situation in the automotive industry in Poland}

\begin{abstract}
Streszczenie: Branża motoryzacyjna stanowi jedną z głównych gałęzi polskiej gospodarki, mając duży udział w wytwarzaniu wartości dodanej brutto i utrzymywaniu miejsc pracy. Pandemia COVID-19 wciąż negatywnie oddziałuje na branżę motoryzacyjną, która przed pandemią była już obciążona licznymi obostrzeniami dotyczącymi m.in. ograniczenia emisji spalin, za sprawą dyrektyw unijnych. Wielkość strat zależna będzie od scenariusza rozprzestrzeniania się wirusa w Polsce, a także skuteczności podjętych działań zaradczych. Celem opracowania jest przedstawienie głównych zmian zachodzących za sprawą wpływu pandemii COVID-19 na produkcję pojazdów samochodowych, przyczep i naczep, poszerzoną o analizę produkcji motocyklii ${ }^{1}$. Przedmiotem przeprowadzonego badania są przedsiębiorstwa funkcjonujące w przemyśle motoryzacyjnym. Zakres czasowy został zdeterminowany dostępnością danych oraz okresem trwania pandemii i w głównej mierze obejmuje rok 2020, niemniej w celu przedstawienia rzetelnego obrazu sytuacji ekonomicznej branży motoryzacyjnej dane odwoływane są również do okresu przedpandemicznego 2018-2019 roku. Na podstawie dostępnych danych statystycznych przeprowadzono analizę, wstępnie szacując poziom strat w branży oraz strukturę wynagrodzenia pracowników. Dokonano również oceny obecnej sytuacji na rynku w zakresie zaistniałych przemian i przyjętych rozwiązań naprawczych.
\end{abstract}

\begin{abstract}
The automotive industry is one of the main branches of the Polish economy, with a large share in generating gross value added and maintaining jobs. The COVID-19 pandemic still has a negative impact on the automotive industry, which before the pandemic was already burdened with numerous restrictions regarding, among others, limitation of exhaust emissions, thanks to EU directives. The size of the losses will depend on the scenario of the virus spreading in Poland, as well as the effectiveness of the remedial actions taken. The aim of the study is to present the main changes taking place due to the impact of the coronavirus pandemic on the production of motor vehicles, trailers and semi-trailers, extended by the analysis of the production of motorcycles. The subject of the research are companies operating in the automotive industry. The time range was determined by the duration of the pandemic and mainly covers the year 2020, however, in order to present a reliable picture of the entire automotive industry, the data is also referenced to the period
\end{abstract}

${ }^{1}$ Produkcja pojazdów samochodowych, przyczep i naczep, z wyłączeniem motocykli - Polska Klasyfikacja Działalności, sekcja 29. 
before the pandemic, i.e. 2018-2019. Based on the available statistical data, an analysis of the existing situation was carried out, initially estimating the level of losses in the industry and the employee remuneration structure. The current situation on the market was also assessed in terms of the changes and the adopted corrective solutions.

Słowa kluczowe: branża motoryzacyjna; COVID-19; pandemia COVID-19; produkcja

Keywords: automotive industry; COVID-19; COVID-19 pandemic; manufacturing

Otrzymano: 14 grudnia 2021

Received: 14 December 2020

Zaakceptowano: 12 marca 2021

Accepted: 12 March 2021

Sugerowana cytacja / Suggested citation:

Stojczew, K. (2021). Ocena wpływu pandemii COVID-19 na sytuację w branży motoryzacyjnej w Polsce. Prace Komisji Geografii Przemysłu Polskiego Towarzystwa Geograficznego, 35(2), 64-84. doi: $10.24917 / 20801653.352 .5$

\section{WSTĘP}

We współczesnych czasach dla branży motoryzacyjnej wraz ze zmieniającym się otoczeniem gospodarczym pojawiają się nowe szanse, takie jak tańsze pozyskiwanie surowców, niższe koszty operacyjne, ale także nowe zagrożenia i przeszkody (Gliński, 2018).

Według Wiedermanna produkcja samochodów to dziedzina przemysłu, która w dużym stopniu oddziałuje na otoczenie zewnętrzne i ma duży wpływ na gospodarkę krajową poprzez generowanie efektu mnożnikowego, co sprawia, że branża motoryzacyjna jest kluczowa z perspektywy rozwoju gospodarczego kraju (Wiedermann, 2007). Pavlínek w swojej pracy dotyczącej sytuacji w przemyśle motoryzacyjnym mającej miejsce w trakcie trwania kryzysu gospodarczego w latach 2008-2009 zauważył, że globalny przemysł motoryzacyjny jest zorganizowany w regionalne klastry, sieci produkcyjne, które są zagnieżdżone w makroregionach takich jak: Ameryka Północna, Ameryka Południowa, czy Unia Europejska. Zgodnie z teorią Pavlínka to regionalne klastry produkcji odzwierciedlają potrzebę geograficznej bliskości najważniejszych dostawców poszczególnych części i podzespołów do montażu pojazdów silnikowych, a także potrzeby wiodących firm motoryzacyjnych, by projektować i produkować pojazdy dostosowane do preferencji konsumentów na poszczególnych rynkach. Należy również podkreślić, że to właśnie Pavlínek zauważył, że podczas kryzysu w latach 2008-2009 regionalna struktura geograficzna światowego przemysłu motoryzacyjnego przyczyniła się do dużych różnic w uzyskanych wynikach regionalnych, natomiast najbardziej dotkliwe skutki kryzysu były odczuwalne w największych regionach produkcyjnych i odpowiadających im krajach (Pavlínek, 2012).

Sytuacja mająca miejsce w 2020 roku mocno zrewidowała dalszą perspektywę rozwoju i generowania zysków dla całego przemysłu motoryzacyjnego. Jak słusznie zauważa Baldwin i Tomiura (2020), już sam fakt, że COVID-19 miała swój początek w centrum produkcyjnym świata, jakim jest Azja Wschodnia, jest szczególnie istotny z perspektywy przemysłu wytwórczego. Po drugie, zakłócenia w łańcuchach dostaw, jakie były następstwem rozprzestrzeniania się pandemii oddziaływały kaskadowo na kolejne państwa. Wyprodukowanie nowego samochodu jest procesem niezwykle złożonym, angażującym, na różnych jego etapach produkcji, liczne podmioty. Jest on 
także ogromnym wyzwaniem organizacyjnym z uwagi na liczbę elementów, komponentów, części i modułów, które należy ze sobą zestawić. Rosnące powiązanie gospodarek poszczególnych krajów, jak i silnie rozbudowana sieć powiązań zewnętrznych i wewnętrznych stwarza zagrożenie w postaci znacznie szybszego rozprzestrzeniania się negatywnych zjawisk w światowym systemie przepływów zarówno zasobów, kapitału, czynników produkcji, jak i usług. W szczególności niepokojąca może być transmisja szoków egzogenicznych wywołana wahaniami koniunkturalnymi w gospodarkach uczestniczących w globalnym układzie sieciowym. Zatem wszelkiego rodzaju szkody m.in. te związane z przerwaniem łańcucha dostaw mogą mieć bardzo znaczący wpływ zarówno na firmy produkcyjne, jak i bezpośrednio na gospodarkę poszczególnych krajów (Łuka, Woźniak, 2012). Rozprzestrzenianie się koronawirusa SARS-CoV-2 na świecie było wydarzeniem bezprecedensowym, a co za tym idzie spowodowana nim pandemia, systematycznie i konsekwentnie negatywnie oddziałuje na kolejnych dostawców poszczególnych elementów składowych samochodów. Kłosińska oraz Dedo-Oledzka (2008) poruszały w swych badaniach naukowych istotę strategii łańcuchów dostaw dla przemysłu motoryzacyjnego, który obecnie za sprawą pandemii jest sukcesywnie zrywany. Jak słusznie zauważa Ivanov, pandemia COVID-19 była w najnowszej historii jednym z najpoważniejszych zakłóceń łańcucha dostaw, która przez swoją siłę osłabiła wiele organizacji na całym świecie. Próbując powstrzymać rozprzestrzenianie się wirusa, większość rządów na całym świecie zareagowała w różnym stopniu, wdrażając środki powstrzymujące podróże ludzi, takie jak zamykanie granic, czy powszechne kwarantanny (Ivanov, 2020). Zerwane z powodu koronawirusa łańcuchy dostaw to nie jedyny problem branży motoryzacyjnej, bowiem wirus bezpośrednio przyczynił się również do znaczącego spadku popytu na nowe samochody, a co za tym idzie, zmniejszenia ilości rejestrowanych pojazdów mechanicznych (KPMG, 2020).

Engel słusznie zauważył już podczas kryzysu ekonomicznego w latach 2008-2010, iż branża motoryzacyjna funkcjonuje jako system naczyń połączonych, co sprawia, że sytuacja, z którą obecnie musimy się mierzyć, odwołuje się do zdarzeń, które miały już miejsce w trakcie kryzysu ekonomicznego w 2008 roku i przypominają efekt domina (Engel, 2008). Obecne spowolnienie gospodarcze może przerodzić się w otwartą recesję, która również nie ominie polskiej gospodarki i jest silnie uzależniona od procesów dokonujących się w skali globalnej. Warto podkreślić, iż poprzednie załamania gospodarcze, w tym również to mające miejsce w latach 2008-2010, były indukowane z zewnątrz, podobnie jest w obecnym przypadku, niemniej pewne przesłanki tego procesu tkwią także w polskiej gospodarce, bowiem dokonując przeglądu funkcjonujących w branży motoryzacyjnej podmiotów gospodarczych można dostrzec, jak istotne są implikacje sprzężeń strukturalnych. Większość przedsiębiorstw funkcjonuje w ramach platformy montażowej, co powoduje, iż jakość i ilość powiązań bezpośrednich inwestycji zagranicznych jest kluczowa dla przewagi konkurencyjnej, a przedsiębiorstwa mogą funkcjonować jedynie pod warunkiem otwartych granic, by doprowadzić do dyfuzji technologii. Rozwój pandemii COVID-19 bezpośrednio oddziałuje nie tylko na producentów części samochodowych, ale również na firmy zajmujące się ich dystrybucją, a także przedsiębiorstwa świadczące usługi serwisowania oraz naprawy pojazdów (KPMG, 2020). Na całym świecie państwa podejmują kroki mające na celu nie tylko zwalczanie choroby u zarażonych ludzi i powstrzymywanie rozprzestrzeniania się wirusa, które mają charakter priorytetowy, ale także ratowanie narażonych na głęboką recesję gospodarek światowych i poszczególnych gałęzi przemysłu istotnych z punktu 
widzenia rozwoju gospodarki. Należy zauważyć, iż na sytuację branży motoryzacyjnej w Polsce wpływa również kondycja firm, które inwestują w Polsce i przenoszą swój kapitał w ramach bezpośrednich inwestycji zagranicznych (Sztaudynger, 2002).

Pandemia COVID-19 w perspektywie długoterminowej będzie miała negatywne skutki zarówno dla europejskich, jak i światowych firm z branży motoryzacyjnej, w tym również polskich, o czym świadczą wskaźniki makroekonomiczne oraz przeprowadzone dotychczas badania międzynarodowych firm audytorskich mające na celu uwypuklenie problemu, z jakim branża motoryzacyjna będzie musiała się skonfrontować. Złożoność procesów, które mają miejsce w trakcie trwania pandemii COVID-19 jest szczególnie istotna ze względu na liczbę podmiotów funkcjonujących w branży motoryzacyjnej i stosunek wypracowywanej przez nie wartości dodanej na rodzimym rynku, co w efekcie przedkłada się na negatywne skutki dla gospodarki.

\section{CEL I METODYKA BADAŃ}

Zastosowany w pracy schemat postępowania wykorzystywał przeprowadzenie badania na podstawie analizy wyników produkcji pojazdów mechanicznych, ilości pojazdów rejestrowanych na rynku, poziomu zobowiązań firm funkcjonujących w branży motoryzacyjnej oraz struktury wynagradzania pracowników. Po zebraniu danych statystycznych oraz analizie oceny ich komplementarności przeprowadzono badanie, którego zakres czasowy wyznaczony był dostępnością danych i w głównej mierze obejmował rok 2020. Niemniej w celu przedstawienia rzetelnego obrazu sytuacji w branży motoryzacyjnej dane odwoływane są do okresu przedpandemicznego lat 2018-2019. Głównym celem artykułu było przedstawienie zmian, jakie zaistniały w przemyśle motoryzacyjnym za sprawą bezprecedensowego wydarzenia, jakim było rozprzestrzenianie się koronawirusa w Polsce. Na potrzeby realizacji głównego celu badawczego niniejszego artykułu przeprowadzono analizę raportów i danych statystycznych dostępnych w bazach Głównego Urzędu Statystycznego, Stowarzyszenia Dystrybutorów i Producentów Części Motoryzacyjnych, renomowanych firm audytorskich funkcjonujących na polskim rynku, a także Polskiego Związku Motoryzacyjnego. Co więcej, dokonano przeglądu literatury przedmiotu związanej z rozwojem branży motoryzacyjnej.

\section{BRANŻA MOTORYZACYJNA W ŚWIETLE LITERATURY PRZEDMIOTU}

Branża motoryzacyjna może być przedmiotem badań co najmniej trzech subdyscyplin geograficznych, takich jak geografia przemysłu, w której przeprowadzane badania dotyczą produkcji samochodów oraz podzespołów wpływających na ich produkcję; geografia usług zajmująca się dystrybucją pojazdów silnikowych, a także geografia rozwoju regionalnego, która poddaje analizie poziom motoryzacji jako jeden ze wskaźników rozwoju społeczno-gospodarczego poszczególnych regionów. W przypadku analizy przestrzennej struktury i organizacji przemysłu samochodowego przeprowadzono wiele badań, które cieszyły się sporym zainteresowaniem polskich geografów takich jak: Domański, Guzik, Gwosdz (2005), Domański i in. (2013), Gwosdz, Micek (2010), Wójtowicz, Rachwał (2014). Niemniej sama specyfika branży motoryzacyjnej w Polsce, podobnie jak w innych krajach Europy Środkowo-Wschodniej, wynika m.in. z faktu, że do roku 1990 rozwijała się ona w warunkach gospodarki centralnie planowanej, która w swoich podstawowych zasadach funkcjonowania jest dalece odmienna od gospodarki 
rynkowej. Jak słusznie zauważa Pucher, do lat siedemdziesiątych XX wieku podaż aut była mocno ograniczona (Pucher, 1995).

Transformacja ustrojowa umożliwiła Polsce włączenie się gospodarki kraju w procesy globalizacyjne i integracyjne, co było bezpośrednio przyczyną kształtowania się rynku. Branża motoryzacyjna w stosunkowo krótkim czasie przeszła zatem trzy momenty krytyczne, jakimi była transformacja ustrojowa, akcesja Polski do UE (Mutrynowski, 2015), a także kryzys światowy, który miał miejsce w latach 2008-2010 (Kudłak i in., 2017). To właśnie w czasie kryzysu gospodarczego zauważono, jak szczególne znaczenie ma branża motoryzacyjna wśród innych sektorów przemysłowych, bowiem negatywne skutki jego oddziaływania odczuli nie tylko producenci samochodów, ale również przedstawiciele całego łańcucha dostawczego, zdominowanego głównie przez małe i średnie przedsiębiorstwa (Dorocki, 2010). Pavlínek w swoich licznych pracach dotyczących wpływu kryzysu ekonomicznego na branżę motoryzacyjną w Europie Środkowo-Wschodniej m.in. „Industrial Upgrading Through Foreign Direct Investment in Central European Automotive Manufacturing”, czy „Upgrading in the automotive industry: firm-level evidence from Central Europe" szczególnie podkreślał rolę, jaką kryzys ekonomiczny w latach 2008-2010 odegrał dla zmiany kierunków rozwoju branży motoryzacyjnej.

W ostatnich trzech dekadach Europa Środkowa doświadczyła znaczącej ekspansji przemysłu motoryzacyjnego (Jürgens, Krzywdzinski, 2009; Pavlínek, Domański, Guzik, 2009). Czechy, Polska, Słowacja i Węgry stały się ważnymi producentami i eksporterami komponentów samochodowych na rynek Europy Zachodniej. Zatem załamanie gospodarcze będące skutkiem pandemii COVID-19 może znacząco oddziaływać nie tylko na polską gospodarkę, ale również gospodarkę państw, w których stosunkowo dużą wartość dodaną dla wypracowania PKB stanowi przemysł motoryzacyjny. W przypadku obecnego kryzysu ekonomicznego wywołanego pandemią COVID-19 wielu badaczy zajmujących się obszarem oddziaływania branży motoryzacyjnej na gospodarkę usiłuje dokonać prognozy przyszłych trendów rozwojowych. Baldwin i Tomiura (2020) w swoich badaniach przedstawiają złożoność zachodzących procesów ukazując, iż pandemia w efekcie dalszego rozwoju przyczyni się do wywołania szoku zarówno po stronie popytowej, jak i podażowej. Należy również podkreślić, iż zakres i całkowity koszt obecnego kryzysu wywołanego pandemią wciąż nie jest w pełni policzalny, wiemy jedynie, że globalne łańcuchy dostaw, które łączą świat z Chinami i innymi ośrodkami produkcyjnymi, zostałyby poważnie zakłócone (Nakamura, Managi, 2020). Można rozważyć dwa możliwe scenariusze skutków dalszego rozwoju pandemii dla przemysłu motoryzacyjnego. Z jednej strony względne wzmocnienie rdzenia produkcji poprzez wspieranie rodzimego przemysłu. Z drugiej strony zaś preferencje konsumentów do zakupu tańszych produktów w czasie kryzysu gospodarczego i rosnącej presji na niższe koszty w firmach wraz ze zmniejszonym popytem na wyższe płace w Europie Środkowej, co w efekcie może skutkować dalszym wzrostem aktywności produkcyjnej w krajach azjatyckich.

\section{CHARAKTERYSTYKA BRANŻY MOTORYZACYJNEJ W POLSCE PRZED PANDEMIĄ COVID-19}

W warunkach postępującej globalizacji, w dobie dynamicznych przemian zachodzących tak w wewnętrznych strukturach przedsiębiorstw, jak i w ich otoczeniu biznesowym podmioty gospodarcze nieustannie muszą poszukiwać nowych sposobów umożliwiających przetrwanie na rynku w stale modyfikujących się warunkach, a także wzmocnienie 
pozycji konkurencyjnej. Informacje dostępne w GUS pozwalają stwierdzić, iż to właśnie rozwój sektora motoryzacyjnego w Polsce jest jednym z kluczowych czynników stymulujących wzrost gospodarczy. Polska jest krajem, który w ostatnich kilkudziesięciu latach przyciągnął znaczące inwestycje zagraniczne w przemyśle motoryzacyjnym i w konsekwencji stał się jednym z największych producentów samochodów, części i podzespołów motoryzacyjnych w Europie Środkowo-Wschodniej. Jednocześnie motoryzacja stała się jedną z kluczowych gałęzi polskiego przemysłu, zarówno pod względem wartości produkcji, zatrudnienia i nakładów inwestycyjnych, jak i udziału w eksporcie. W 2019 roku wartość eksportu przemysłu motoryzacyjnego z Polski wzrosła do poziomu 27,85 mld euro. Co stanowiło 1,89 mld euro więcej niż rok wcześniej a jednocześnie ustanowiło nowy rekord w tej branży. Co więcej, Polska jest także największym w regionie rynkiem, jeżeli chodzi o sprzedaż i usługi związane z motoryzacją. Wartość produkcji sprzedanej w branży motoryzacyjnej w 2019 roku wyniosła ponad 160,7 mld złotych, co stanowiło niemalże 4\% sumarycznej wartości dodanej brutto w gospodarce i 10,5\% wartości produkcji sprzedanej w tej części gospodarki (KPMG, 2019).

Polska za sprawą przystąpienia do Unii Europejskiej, a także dzięki licznym preferencjom związanym z tworzeniem Specjalnych Stref Ekonomicznych oraz stosunkowo niskim kosztom pracy w relacji do kwalifikacji i motywacji zawodowej pracowników stała się liczącym partnerem w produkcji samochodów zarówno osobowych, dostawczych, jak i autobusów. Dodatkowo sektory powiązane z motoryzacją, a więc motoryzacyjne usługi finansowe i biznesowe, transport drogowy, produkcja i handel paliwami oraz infrastruktura drogowa, generują łącznie 58,2 mld złotych wartości dodanej, tj. 3,5\% wartości dodanej brutto w gospodarce ogółem (KPMG, 2019)· Warto zwrócić uwagę, że Polska jest liczącym się producentem samochodów użytkowych, nie tylko w skali Europy Środkowo-Wschodniej, ale Europy w ogóle. Więcej pojazdów z tego segmentu produkowanych jest w Hiszpanii, Francji, Niemczech i Włoszech, są to jednak kraje o większym przemyśle motoryzacyjnym i nieporównywalnie silniejszym rynku wewnętrznym. Pozycja Polski w tym segmencie umocniła się w 2017 roku, kiedy fabryka Volkswagena we Wrześni osiągnęła pełną operacyjność (Misztalewski, Daniluk, 2018).

Raport przygotowany przez firmę audytorską z tzw. „wielkiej czwórki” - KPMG przytacza, iż rozwój sektora motoryzacyjnego w Polsce - w głównej mierze napędzany jest przez zakupy i dobrą jakość oferowanych na rynku produktów. Poza produkcją samochodów warto również zaznaczyć, że kluczową rolę odgrywa eksport akcesoriów i części samochodowych, których udział w rynku stanowi aż 86 mld złotych i z roku na rok rośnie. Dostępne pomiary wykazują, iż do głównych przewag rodzimej branży motoryzacyjnej do niedawna należała stosunkowo tania siła robocza, natomiast obecnie jest to wysoka jakość i oferowane przez przedsiębiorstwa innowacyjne rozwiązania i nowe technologie (Misztalewski, Daniluk, 2018). Wdrażanie innowacji w polskiej branży motoryzacyjnej może przyczynić się do zwiększenia znaczenia branży dla całej gospodarki. Dlatego też w przypadku przedsiębiorstw z polskim kapitałem statystyki wykazują, iż konieczne jest podjęcie dodatkowych działań zwiększających rozmach inwestycyjny, jaki przyczyni się do tworzenia rodzimych jednostek badawczo-rozwojowych bezpośrednio z polskim kapitałem bądź podejmowanie współpracy ze środowiskiem naukowym w tym zakresie. W 2019 roku zmalała produkcja samochodów osobowych i dostawczych o dopuszczalnej masie całkowitej do 3,5 tony. Działające w Polsce fabryki zmniejszyły produkcję o 1,7\% w porównaniu do 2018 roku. Rok wcześniej spadek wyniósł 5,4\%. Ze wszystkich fabryk, według danych dostarczonych przez producentów, wyjechało 621,8 
tys. samochodów osobowych i lekkich dostawczych. Poniższa tabela przedstawia dane dotyczące produkcji poszczególnych modeli pojazdów wśród liderów funkcjonujących na polskim rynku.

Tabela 1. Liczba pojazdów wyprodukowanych w trzech największych fabrykach w Polsce 2019 roku w szt.

\begin{tabular}{|l|l|c|c|}
\hline \multicolumn{1}{|c|}{ Producent } & \multicolumn{1}{|c|}{ Marka } & Liczba szt. & \multicolumn{1}{c|}{$\begin{array}{c}\text { Zmiana } \% \\
\text { do 2018 r. }\end{array}$} \\
\hline \multirow{3}{*}{ FCA POLAND } & Fiat 500 & 200704 & $-4,91 \%$ \\
\cline { 2 - 4 } & Lancia Ypsilon & 62472 & $29,14 \%$ \\
\hline \multirow{2}{*}{ Volkswagen Poznań } & Caddy 4 & 148334 & $-7,89 \%$ \\
\cline { 2 - 4 } & Crafter & 72703 & $8,69 \%$ \\
\cline { 2 - 4 } & Transporter T6 & 29342 & $-1,80 \%$ \\
\hline $\begin{array}{l}\text { Opel Manufacturing Poland } \\
\text { (obecnie PSA Group) }\end{array}$ & Astra & 92500 & $-13,11 \%$ \\
\hline
\end{tabular}

Źródło: Opracowanie własne na podstawie raportu Europejskiego Stowarzyszenia Producentów Samochodów (ACEA) 2019 (ACEA, 2020b)

Największą fabryką w Polsce został po raz drugi Volkswagen Poznań. Jego udział sięgnął 43\% w krajowej produkcji samochodów osobowych i lekkich dostawczych, był minimalnie wyższy niż rok wcześniej. Dwa zakłady należące do spółki Volkswagen Poznań wyprodukowały 266,1 tys. aut osobowych i lekkich dostawczych, o 0,26\% mniej niż rok wcześniej. Podobna sytuacja miała miejsce w zakładach Fiat Chrysler Automobiles Poland w Tychach, gdzie w 2019 roku wyprodukował 263,2 tys. aut, o 1,4\% mniej niż w 2018 roku. Spadek produkcji w 2019 roku zanotował także gliwicki zakład Opel Manufacturing Poland. Z taśmy zakładu zjechało 92,5 tys. aut, o 13,1\% mniej niż rok wcześniej. Dane świadczące o wielkości produkcji w okresie przedpandemicznym świadczyły o pojawiających się już sygnałach dotyczących powolnego spadku wielkości produkcji w polskich fabrykach samochodowych. Natomiast okres rozprzestrzeniania się koronawirusa SARS-CoV-2 jedynie zwiększył ilość potencjalnych problemów, na które obecnie narażona jest branża motoryzacyjna (ACEA, 2020a).

W 2019 roku w Polsce najpopularniejsze według analiz Centralnej Ewidencji Pojazdów okazały się auta osobowe z silnikami benzynowymi. Ten rodzaj napędu zdobył 70,5\% rynku, a liczba rejestracji zwiększyła się o 6,5\% do 391,9 tys. Udział aut wyposażonych w diesle zmalał do 19,9\%. Liczba rejestracji wyniosła 110,6 tys. i była o 15,4\% mniejsza niż rok wcześniej. 0 72,6\% wzrosła liczba rejestracji modeli hybrydowych, do 41,9 tys. Ten rodzaj napędu zdobył 7,5\% rynku, co oznacza 3 punkty procentowe więcej niż rok wcześniej. Samochody elektryczne czerpiące prąd z baterii liczone łącznie z hybrydami plug-in zanotowały 95,3-procentowy przyrost liczby rejestracji, do 2,7 tys., z czego 1,5 tys. przypadło na napęd bateryjny, reszta na hybrydowy ładowany z gniazdka. Dla porównania, według danych Europejskiego Stowarzyszenia Producentów Samochodów - ACEA, w 2019 roku w Niemczech zarejestrowano 108839 pojazdów z napędem elektrycznym, w Norwegii 79 640, natomiast w Wielkiej Brytanii 72 834. Należy jednak zaznaczyć, że we wszystkich wymienionych państwach obowiązuje rozbudowany system wsparcia finansowego nabywców samochodów z napędem elektrycznym. Okres trwania pandemii COVID-19 stanowi wyzwanie również dla rozwoju polskiej elektormobilności, bowiem już w okresie przedpandemicznym w Polsce liczba pojazdów z napędem elektrycznym była znacząco niższa w odniesieniu do innych europejskich państw. 


\section{OCENA ZMIAN W PRZEMYŚLE MOTORYZACYJNYM W POLSCE W TRAKCIE TRWANIA PANDEMII COVID-19 - WYNIKI BADAŃ}

Polskie fabryki funkcjonujące w branży motoryzacyjnej, takie jak: Zakład Tychy FCA Poland SA, Toyota Motor Manufacturing Poland Sp. z o.o. w Wałbrzychu, Grupa PSA w Gliwicach, MAN Bus Sp. z o.o. w Starachowicach i Niepołomicach czy Volkswagen w Poznaniu w początkowym etapie pandemii niemalże zaprzestały produkcji. Okres całkowitego lockdownu był zróżnicowany w poszczególnych przedsiębiorstwach, niemniej w większości z nich trwał nieprzerwanie niemalże trzy miesiące. Należy również podkreślić, iż równocześnie działania te pociągnęły za sobą decyzje o czasowym zawieszeniu pracy w zakładach produkujących podzespoły dla zamkniętych fabryk. Dokonując pewnej systematyzacji i podziału branżowych raportów dostępnych za sprawą badań prowadzonych przez firmy audytorskie można dostrzec w nich pewną dwutorowość, analizy opierały się głównie na badaniach dotyczących produkcji samochodów oraz podzespołów wpływających na ich produkcję. Takie firmy jak Deloite, PwC, czy KPMG przeprowadziły analizę zachowań firm produkcyjnych, w tym również tych funkcjonujących w branży motoryzacyjnej w trakcie trwania pandemii. Natomiast z drugiej strony takie podmioty jak Stowarzyszenie Producentów Samochodów, czy też PZPM przeprowadziły analizę sprzedaży pojazdów mechanicznych i przedstawiły zmiany, jakie w niej zaszły w trakcie trwania pandemii. Sprzedaż fabrycznie nowych samochodów według raportu przedstawionego przez ACEA początkowo spadła nawet o 50\%. Niemal całkowicie został zniwelowany popyt na nowe samochody, co w efekcie oznaczało także dla producentów komponentów długookresowe przestoje. Jak wynika z nowych danych statystycznych, które zostały opublikowane przez Europejskie Stowarzyszenie Producentów Samochodów (ACEA, 2020a), zamknięcie fabryk w wyniku kryzysu wywołanego przez COVID-19 w pierwszym kwartale 2020 roku doprowadziło do utraty znacznego wolumenu produkcji (KPMG, 2020). Według ekspertów firmy audytorskiej KPMG, zajmujących się badaniem branży motoryzacyjnej, oszacowane zostało, iż wartość dodana sektora motoryzacyjnego dla polskiej gospodarki w 2020 roku w scenariuszu bazowym nieuwzględniającym występowania epidemii COVID-19 wynosiłaby 113,8 mld zł. Po aktualizacji wartości dodanej poszczególnych sektorów, dokonanej na podstawie zrewidowanej prognozy wzrostu PKB na 2020 rok, oszacowano, że w zależności od tempa wzrostu gospodarczego w sektorze motoryzacyjnym może ona wynieść od 106,3 mld zł do 112,4 mld zł. Tego rodzaju korekty wyliczeń dokonano ze względu na zmniejszenie popytu na samochody wśród odbiorców, a także braki dostaw części motoryzacyjnych produkowanych w 2020 roku w rejonach najmocniej dotkniętych epidemią koronawirusa (KPMG, 2020).

Na rycinie 1 przedstawiono dane statystyczne pochodzące z bazy GUS, podające, jak w poszczególnych kwartałach 2019 oraz 2020 roku kształtował się w Polsce wolumen produkcji samochodów osobowych, środków transportu publicznego oraz samochodów ciężarowych.

Według danych statystycznych produkcja samochodów osobowych w 2020 roku w Polsce w porównaniu do 2019 roku zmniejszyła się o 144,7 tys. sztuk. Liczba sztuk wyprodukowanych w polskich fabrykach w kwietniu 2020 osiągnęła bowiem zaledwie 400 jednostek. W porównaniu do ubiegłego roku oznaczało to spadek o 43 tys. sztuk. W przypadku produkcji pojazdów transportu publicznego sytuacja kształtowała się nieco lepiej, bowiem różnice w liczbie wyprodukowanych sztuk znacząco nie odbiegały od 
Rycina 1. Produkcja w przemyśle motoryzacyjnym w sztukach, w Polsce latach 2019-2020

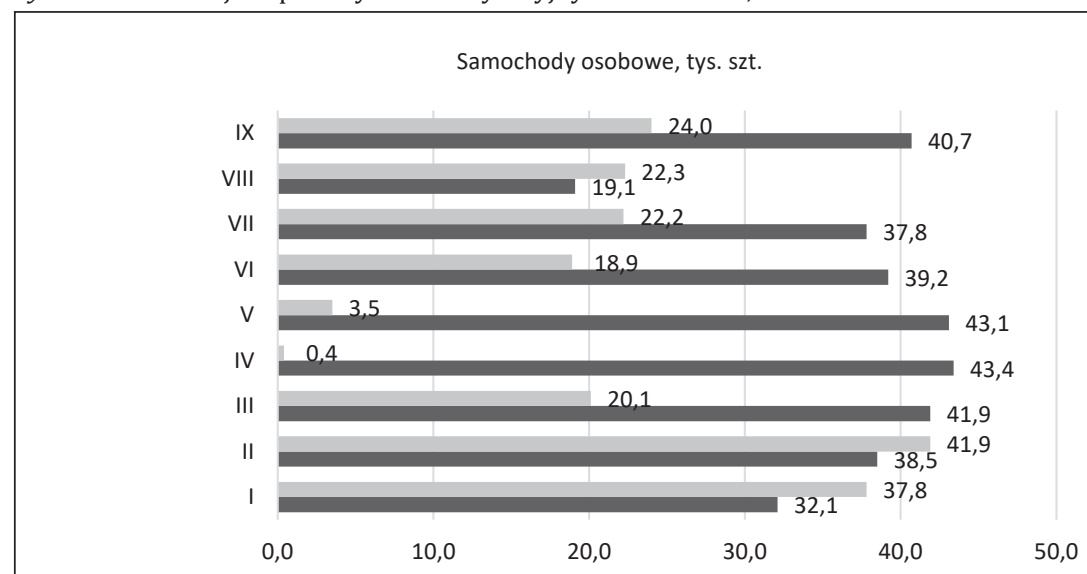

Pojazdy transportu publicznego

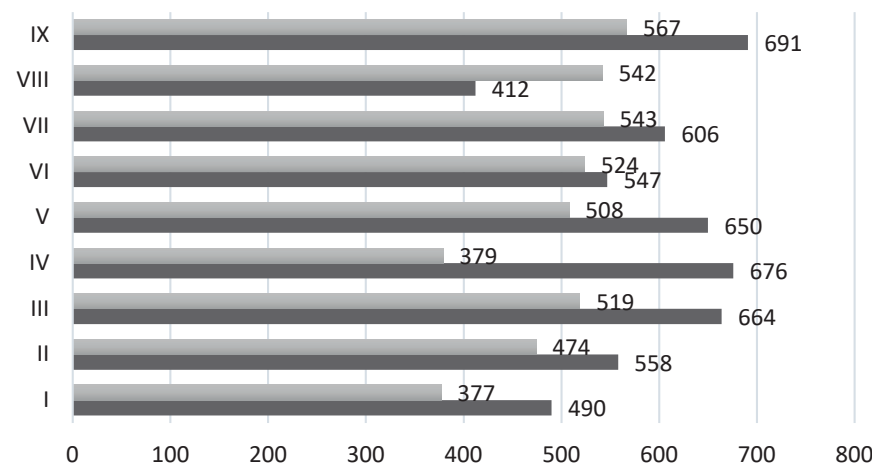

Samochody ciężarowe, tys. szt.

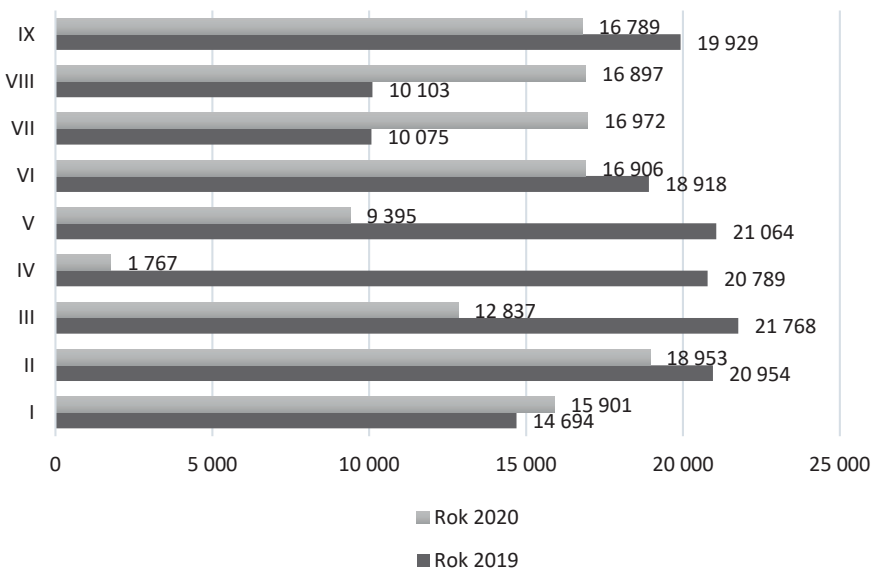

Źródło: opracowanie własne na podstawie danych GUS, Produkcja wyrobów przemysłowych 2019-2020 


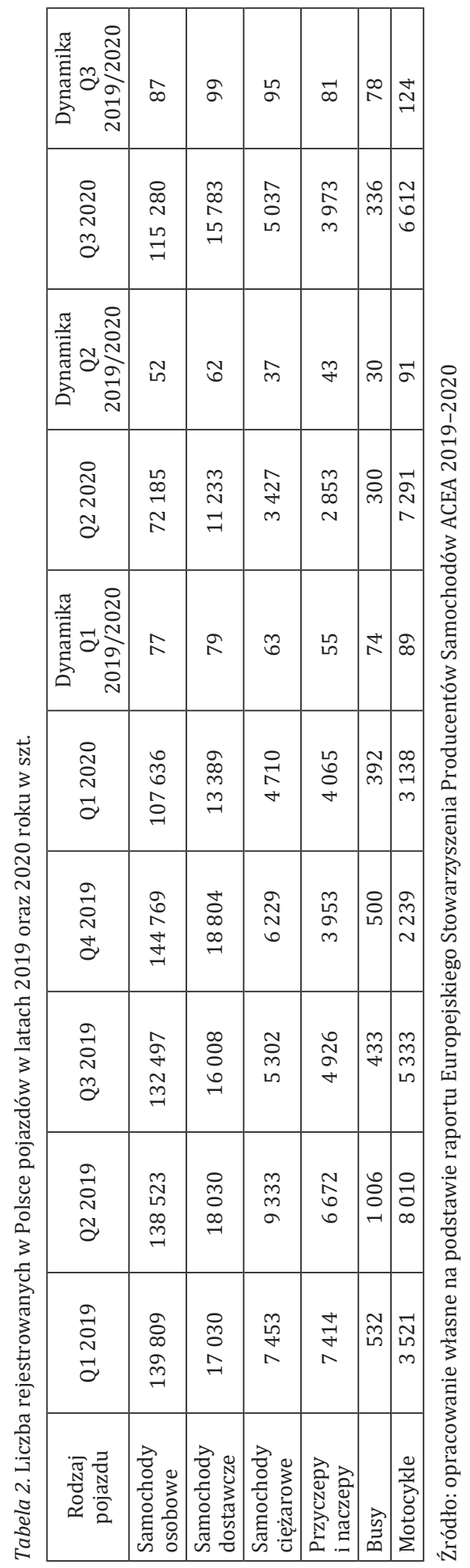


wyników osiągniętych w 2019 roku. W polskich fabrykach produkowane jest znacznie mniej środków transportu publicznego niż samochodów osobowych. Można zauważyć, iż produkcja trwała nieprzerwanie i utrzymywała się na stałym poziomie w granicach 500 sztuk miesięcznie, za wyjątkiem dwóch miesięcy, stycznia i kwietnia 2020 roku, kiedy odnotowano największy spadek produkcji. Warto podkreślić, iż również w okresie przerw wakacyjnych, w których zazwyczaj zmniejszona jest aktywność produkcyjna, produkcja pojazdów transportu publicznego utrzymywała się na stałym poziomie. W przypadku samochodów ciężarowych, podobnie jak w dwóch poprzednich grupach pojazdów, największy spadek odnotowano w miesiącu kwietniu 2020 roku. Podobnie jak w przypadku produkcji pojazdów transportu publicznego, fabryki produkujące samochody ciężarowe usiłowały zniwelować straty produkcyjne w miesiącach letnich, które w okresie, kiedy nie występowała pandemia, utożsamiane były z obniżoną podażą produkcji (GUS, 2020).

W celu przedstawienia szerszej charakterystyki zmian zachodzących w przemyśle motoryzacyjnym podczas pandemii COVID-19, w tabeli 2 ukazano, jak kształtował się wolumen rejestrowanych samochodów osobowych, ciężarowych, naczep, motorów i skuterów w 2020 roku w odniesieniu do poszczególnych kwartałów 2019 roku.

Według danych przygotowanych przez SDCM, spadek liczby rejestrowanych pojazdów w 2020 roku nastąpił w każdej kategorii pojazdów w porównaniu do liczby rejestrowanych pojazdów w 2019 roku. Największe dysproporcje możemy zaobserwować w przypadku samochodów osobowych, bowiem rejestrowanych jest ich w Polsce najwięcej. Najmniejszą liczbę pojazdów zarejestrowano w drugim kwartale 2020 roku, zmiana do drugiego kwartału 2019 roku wyniosła niemalże 85 tysięcy pojazdów. Można zatem wnioskować, iż wolumen rejestrowanych środków transportu zmniejszył się aż o połowę w odniesieniu do roku ubiegłego. Można również dostrzec pewne pozytywne symptomy zmian wskaźników, które odzwierciedlają przyrost rejestrowanych pojazdów mechanicznych już w trzecim kwartale 2020 roku. Grupą pojazdów silnikowych, która odnotowała wzrost liczby rejestracji w trzecim kwartale 2020 roku, w porównaniu do roku 2019, były motocykle. Wynikać to może ze wzmożonego zapotrzebowania na usługi dostarczania drobnych przesyłek bądź posiłków, które są świadczone z wykorzystaniem tego rodzaju pojazdów silnikowych. Jak można zauważyć, dane statystyczne stanowią, iż procentowo najwyższy spadek rejestracji odnotowano w przypadku samochodów ciężarowych, przyczep i naczep, co bezpośrednio może być przyczyną problemów, z jakimi zmaga się obecnie branża logistyczna. Sytuacja firm logistycznych w dobie pandemii w oczywisty sposób różnicuje się ze względu na stopień uzależnienia od zamówień konkretnych branż. Firmy logistyczne, które obsługują branże, w których sprzedaż towarów w praktyce zamarła, jak np. samochodów i akcesoriów motoryzacyjnych (zdecydowany spadek aktywności zakupowej odnotowuje w tym zakresie aż 72\% firm logistycznych, które były odpowiedzialne za dostarczenie komponentów i części samochodowych), mają znaczne problemy z uzyskaniem przewagi konkurencyjnej nad firmami, które obsługują klientów detalicznych. Ponadto zamknięte granice, nowe obostrzenia oraz zerwane łańcuchy dostaw znacząco utrudniają codzienną pracę firm logistycznych (Stowarzyszenie Dystrybutorów..., 2020).

W celu przedstawienia zmian, jakie zaistniały w przemyśle motoryzacyjnym w trakcie trwania pandemii COVID-19, w tabeli 3 przedstawiono, jak kształtował się poziom zobowiązań firm zajmujących się produkcją pojazdów silnikowych w 2020 roku w odniesieniu do roku bazowego 2019. 
Tabela 3. Zobowiązania przedsiębiorstw z branży motoryzacyjnej w Polsce w latach 2019-2020 w mln zł

\begin{tabular}{|l|c|c|c|c|c|}
\hline \multicolumn{1}{|c|}{$\begin{array}{c}\text { Sekcje } \\
\text { i działy }\end{array}$} & Długoterminowe & Krótkoterminowe & $\begin{array}{c}\text { Kredyty } \\
\text { bankowe } \\
\text { i pożyczki }\end{array}$ & $\begin{array}{c}\text { Z tytułu } \\
\text { dostaw } \\
\text { i usług }\end{array}$ & $\begin{array}{c}\text { Relacja } \\
\text { zobowiązań } \\
\text { krótkoterminowych } \\
\text { do należności }\end{array}$ \\
\hline $\begin{array}{l}\text { Produkcja } \\
\text { pojazdów } \\
\text { samochodowych, } \\
\text { przyczep } \\
\text { i naczep 2020 }\end{array}$ & 12583,6 & 38831,7 & 9341,5 & 17609,7 & 108,6 \\
\hline $\begin{array}{l}\text { Produkcja } \\
\text { pojazdów } \\
\text { samochodowych, } \\
\text { przyczep } \\
\text { i naczep 2019 }\end{array}$ & 10015,3 & 41103,3 & 5892,4 & 24146,2 & 109,6 \\
\hline $\begin{array}{l}\text { Dynamika zmian } \\
\text { zobowiązań }\end{array}$ & 126 & 94 & 159 & 73 & 99 \\
\hline
\end{tabular}

Źródło: opracowanie własne na podstawie danych GUS. Produkcja wyrobów przemysłowych w latach 2019-2020

Dokonując analizy powyższych danych można zauważyć, iż największe zmiany w zakresie dynamiki zmian dotyczyły wzrostu kredytów bankowych i pożyczek, które zwiększyły swą wartość aż o 3449,1 mln zł w porównaniu do roku 2019, dynamika zmian wynosiła 159\%, co może bezpośrednio świadczyć o pogarszającej się sytuacji finansowej przedsiębiorstw funkcjonujących w branży. Równie dużą dynamiką charakteryzowały się zmiany zobowiązań długoterminowych, bowiem wartość wskaźnika dynamiki w 2020 roku do roku 2019 wyniosła 126\%. Znacząco zmieniły się również zobowiązania z tytułu dostaw i usług - w ciągu roku dynamika zmian tych wartości zmniejszyła się niemalże o 30\%, czyli o 6536,5 mln zł. Tego rodzaju zależność może mieć miejsce głównie ze względu na zerwane łańcuchy dostaw części i podzespołów do fabryk, które zajmują się produkcją finalnych wyrobów.

Stowarzyszenie Dystrybutorów i Producentów Części Motoryzacyjnych, przeprowadziło w grudniu 2020 roku badanie ankietowe dotyczące trzech pierwszych kwartałów 2020 roku. Wśród respondentów badania znaleźli się główni polscy producenci części motoryzacyjnych. Miało ono na celu przedstawienie, z jakimi problemami muszą się oni borykać i co stanowi największe zagrożenie dla ich dalszej działalności gospodarczej w nowej rzeczywistości. Ponad 70\% respondentów wykazała, że ma problemy z anulowanymi bądź znacznie ograniczonymi zamówieniami z powodu szerzenia się pandemii, co w efekcie powoduje dalsze zakłócenia, a podejmowane działania w związku z anulowanymi, czy ograniczanymi zamówieniami mają wpływ na kolejne firmy, także spoza branży motoryzacyjnej, co pogłębia efekt domina i dysproporcje w rozwoju przedsiębiorstw (Stowarzyszenie Dystrybutorów..., 2020).

Zarówno branża producentów samochodów, jak i dealerów samochodów, aktywnie reaguje na skutki epidemii na wielu płaszczyznach swojej działalności między innymi przygotowując szereg krótkookresowych działań zaradczych, do których można zaliczyć: prowadzenie negocjacji z importerami części i surowców między innymi na temat wydłużenia okresów płatności, czy zmian w planach sprzedażowych. Przygotowywany jest katalog tak zwanych „dobrych praktyk” w zakresie bezpieczeństwa pracowników i klientów oraz działań umożliwiających stabilne i ciągłe funkcjonowanie firm dealerskich i produkcyjnych w czasach kryzysu wywołanego pandemią COVID-19 
(KPMG, 2020). Niestety należy również zaznaczyć, iż szerząca się pandemia to nie jedyny problem, z jakim muszą się zmagać producenci samochodów i części samochodowych. Według opublikowanych danych w styczniu bieżącego roku sprzedaż samochodów osobowych w Unii Europejskiej zmalała w ujęciu rocznym niemalże o 7,5 punktów procentowych, do 956,8 tys. sztuk. Wynik ten to pierwszy spadek po pięciu kolejnych miesiącach nieprzerwanych wzrostów odnotowywanych w branży. Według analiz najmniejszy popyt na nowe samochody wśród krajów Unii Europejskiej odnotowano w Szwecji, gdzie kierowcy kupili ich aż o 18\% mniej niż w roku ubiegłym. W przypadku Polski sytuacja była niewiele korzystniejsza. Z wynikiem na poziomie minus 14,1 punktów procentowych, Polska była na drugim miejscu zestawienia krajów z najniższą sprzedażą odnotowaną w kwietniu 2020 roku (KPMG, 2020).

W analizowanych badaniach respondenci zostali również zapytani o planowane działania antykryzysowe, które zostaną zainicjowane w przedsiębiorstwach przez nich zarządzanych. Najczęściej wskazywane odpowiedzi na to pytanie, to zastopowanie planowanych bądź trwających już inwestycji w rozwój firmy. Brak inwestycji będzie naturalnym krokiem dla wielu firm, co negatywnie wpłynie na całą gospodarkę, a zarazem będzie pogłębiało trudną sytuację innych świadczących dla nich usługi, czy sprzedających swoje produkty. Co trzeci z respondentów natomiast w ramach działań antykryzysowych zadeklarował, iż przyjrzy się dokładnie wynagrodzeniom swoich pracowników.

Skutki pandemii COVID-19 oddziałują nie tylko na producentów samochodów, ale także na sektor handlu i napraw pojazdów samochodowych. Zgodnie z informacjami pozyskanymi przez firmę audytorską Ernst and Young, która przeprowadziła badania wśród 6 czołowych dealerów na polskim rynku samochodów, ruch klientów w salonach samochodowych pod koniec pierwszego kwartału 2020 roku był znikomy, a z usług serwisowych korzystało szacunkowo 40-50\% klientów mniej niż zazwyczaj w tym samym okresie w ubiegłych latach (Ernst and Young, 2020). W drugiej połowie roku 2020 sytuacja nieco się polepszyła, osiągając wyniki zbliżone do roku bazowego 2019. Niemniej, eksperci podkreślają, iż nierealizowanie planów sprzedażowych przewidzianych na 2020 rok przez dealerów oraz brak klientów w serwisach, w krótkim czasie mogą spowodować problemy z płynnością finansową, a co z tym związane redukcję zatrudnienia (Stowarzyszenie Dystrybutorów..., 2020).

Główny Urząd Statystyczny opublikował dane dotyczące zarobków pracowników w przemyśle motoryzacyjnym według PKD 29 w trzech pierwszych kwartałach 2020 roku. Na rycinie 2 przedstawiono, jak kształtował się odsetek osób wynagradzanych w poszczególnych przedziałach płacowych w 2020 roku w odniesieniu do bazowego 2019.

Dane dotyczące przeciętnego wynagrodzenia pracowników zatrudnionych w przemyśle motoryzacyjnym pozwalają stwierdzić, że wysokość zarobków w poszczególnych przedziałach uległa zmianie i w najwyższym przedziale uległa obniżeniu o 7 punktów procentowych. Można zauważyć, iż doszło do pewnego rodzaju przesunięcia osób o wynagrodzeniu 6000,01 i więcej do przedziałów niższych, 5000,01-6000 oraz 4000,01-5000. Tego rodzaju prawidłowość mogła być spowodowana z jednej strony zmieniającymi się uwarunkowaniami ekonomicznymi działalności przedsiębiorstw, brakiem projektów i zamówień, z drugiej natomiast strony, związane to być mogło z obniżaniem wynagrodzenia w związku z wdrożeniem przepisów związanych ze zwalczaniem negatywnych skutków pandemii i wejściem w życie tzw. rozwiązań „postojowych” dla pracowników. 
Rycina 2. Struktura wynagrodzenia brutto w firmach z branży motoryzacyjnej w latach 2019-2020

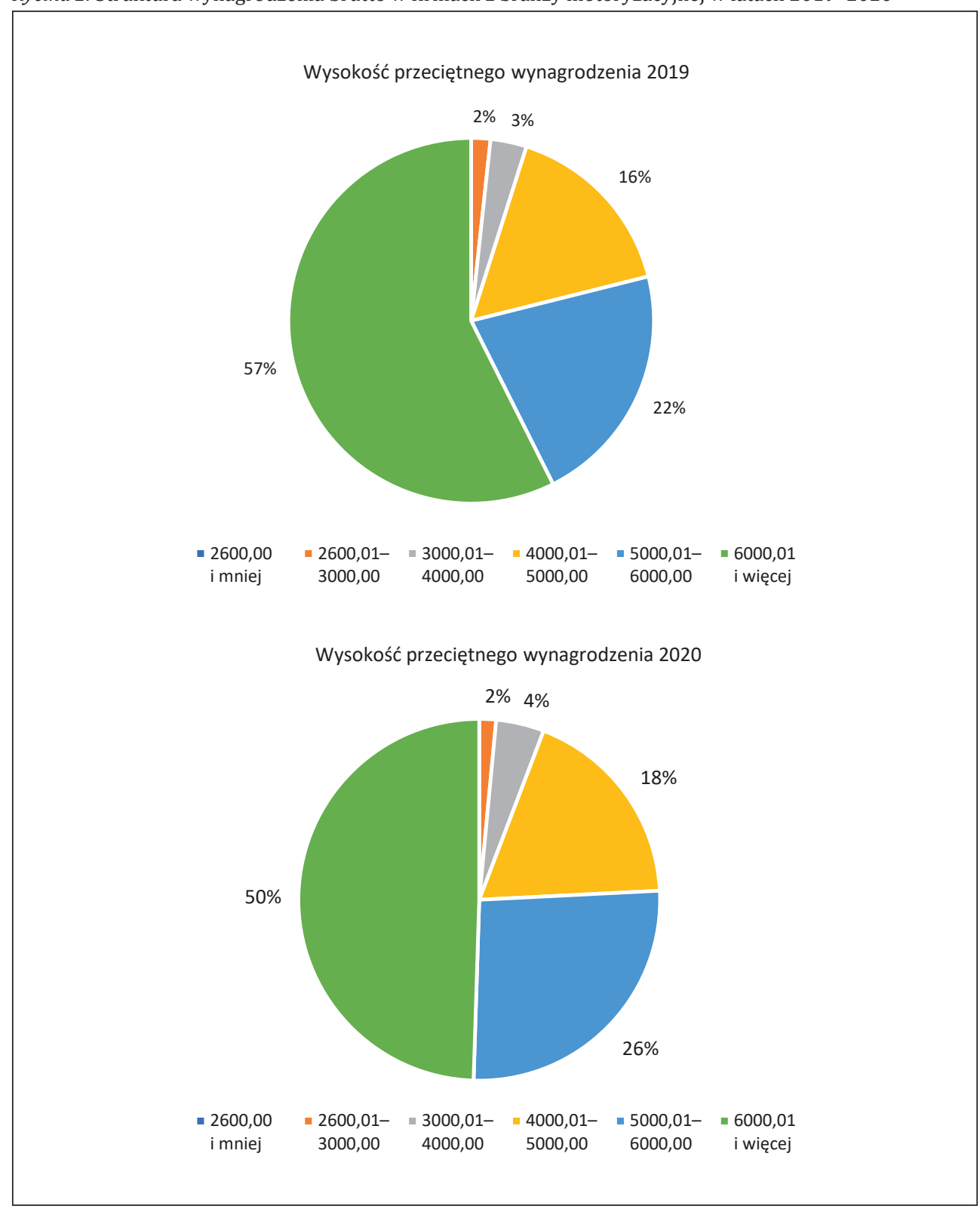

Źródło: opracowanie własne na podstawie danych statystycznych GUS. Produkcja wyrobów przemysłowych 2019-2020

Według raportu opublikowanego w grudniu 2020 roku przez Polski Związek Przemysłu Motoryzacyjnego „Automotive Industry Report 2020-2021”, w którym zebrano odpowiedzi przedstawicieli firm zajmujących się produkcją części samochodowych i podzespołów z obszaru Dolnego Śląska, niemalże jedna trzecia firm z branży motoryzacyjnej zgodnie z przewidywaniami odnotowała w 2020 roku ponad 50\% spadek 
Rycina 3. Badanie wielkości spadku przychodów przedsiębiorstw funkcjonujących w branży motoryzacyjnej w Polsce w roku 2020

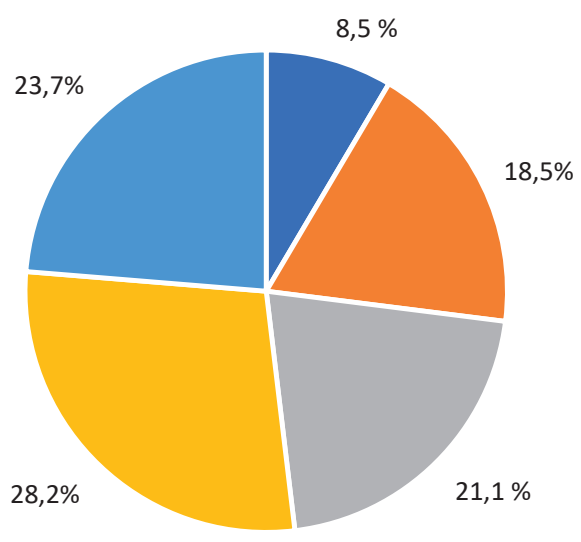

- nie przewidujemy spadku przychodów

nie wiem

niędzy 10 a $25 \%$

- powyżej $50 \%$

- między 25 a $50 \%$

Źródło: opracowanie własne na podstawie danych PZPM „Automotive Industry Report 2020-2021”

przychodów w porównaniu do roku 2019, a kolejne 23,7\% przedsiębiorstw ocenia, że spadek wyniósł między 25 a 50\%. Rycina 3 przedstawia, jak kształtowała się w Polsce wielkość spadku przychodów przedsiębiorstw funkcjonujących w branży motoryzacyjnej w 2020 roku.

Wśród badanych przedsiębiorstw jedynie co dziesiąta firma nie odnotowała spadków w porównaniu z 2019 rokiem. Ponad 66\% ankietowanych firm w dalszym ciągu odczuwa niepewność i nie jest w stanie przewidzieć dalszego wpływu pandemii na ich działalność. Niemal 21\% przedsiębiorstw zauważa złe perspektywy dla swojej działalności, z realną wizją zwolnień lub przebranżowienia firmy. Jedynie 8,5\% podmiotów gospodarczych funkcjonujących w branży motoryzacyjnej ocenia, że obecna sytuacja pandemiczna nie ma wpływu na prowadzoną przez nich działalność.

W przypadku perspektyw rozwojowych działalności gospodarczej wykazano, iż 87\% podmiotów funkcjonujących w branży motoryzacyjnej odczuje negatywne skutki w przypadku, gdy pandemia COVID-19 będzie trwała do połowy 2021 roku, 66\% przedsiębiorstw odczuwa niepewność związaną z sytuacją rynkową, natomiast skutki pandemii w przyszłości są trudne do przewidzenia. Rycina 4 przedstawia, jak kształtują się według respondentów perspektywy rozwoju branży motoryzacyjnej w Polsce w 2021 roku.

Według analizowanych danych, aż 87\% respondentów dalszą przyszłość branży motoryzacyjnej postrzega jako niestabilną i niepewną. Ponadto został zasygnalizowany szczególnie istotny problem z perspektywy dalszego funkcjonowania branży, mianowicie istota wsparcia rządowego. Niemalże 21\% respondentów podkreśla, iż bez dodatkowej pomocy wystąpi ryzyko przebranżowienia bądź zwolnień pracowników. 
Rycina 4. Perspektywy rozwoju branży motoryzacyjnej w Polsce w 2021 roku

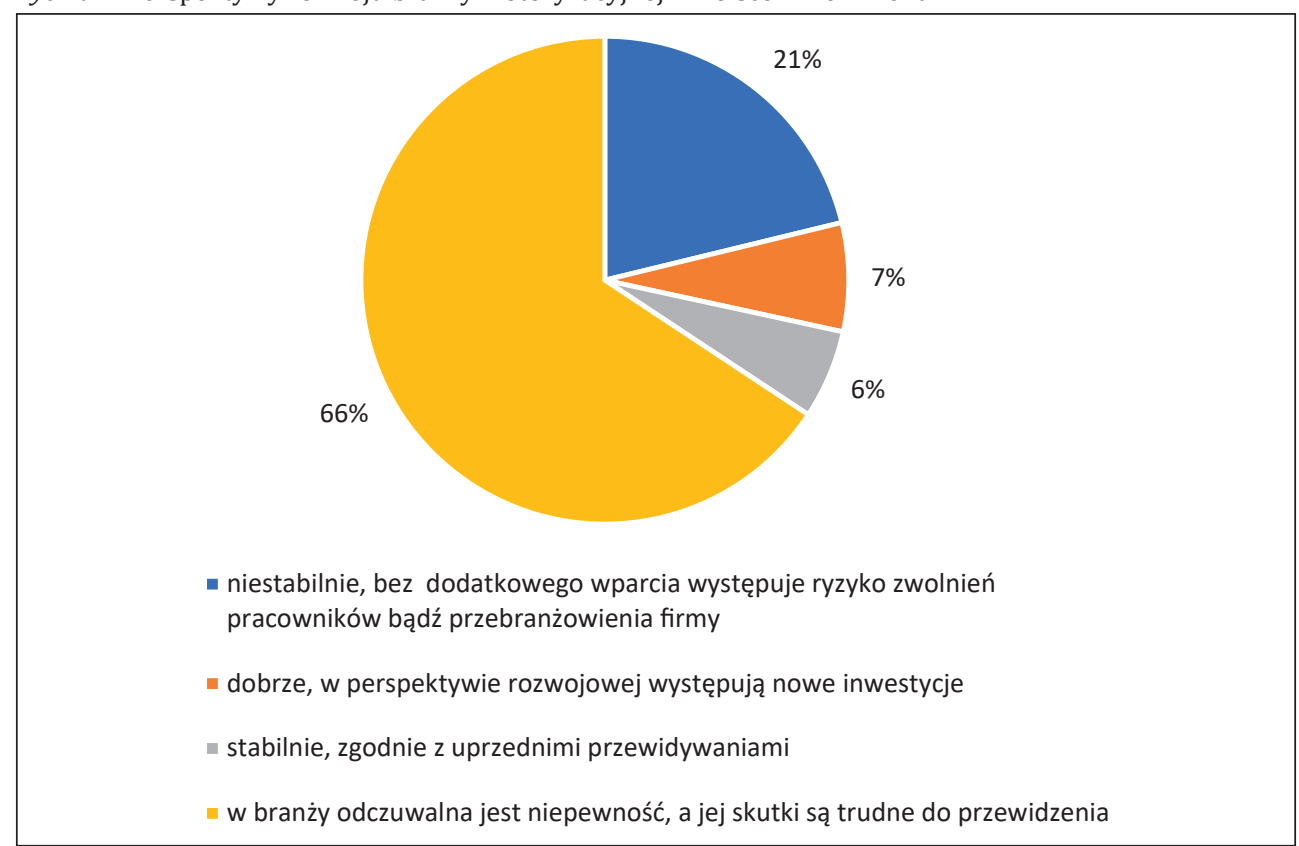

Źródło: opracowanie własne na podstawie danych PZPM „Automotive Industry Report 2020-2021”

Ponadto przeanalizowano dane dotyczące trudności związanych $\mathrm{z}$ funkcjonowaniem przedsiębiorstw w dobie rozprzestrzeniania się koronawirusa SARS-CoV-2. $\mathrm{Z}$ analizy wynika, iż zdecydowana większość przedsiębiorstw wymieniła 4 kluczowe aspekty: problemy z terminowymi dostawami, trudności związane z absencją chorobową pracowników, opóźnienie w płatnościach, a przede wszystkim, co wykazało niemalże $60 \%$ badanych podmiotów gospodarczych, spadek liczby zamówień.

\section{WNIOSKI I DYSKUSJA}

Według przeprowadzonych analiz dla producentów samochodów i części samochodowych najbliższa przyszłość jest szczególnie narażona na wystąpienie kryzysu ekonomicznego w perspektywie długoterminowej. Przyczynia się do tego zarówno pandemia COVID-19, jak i szereg innych czynników rzutujących na branżę. Należy podkreślić, iż ani spowolnienie gospodarcze państw członkowskich Unii Europejskiej, ani problemy związane z Brexitem, ani w końcu pandemia szybko nie znikną. Wobec zmniejszonego popytu, spowodowanego m.in. rozprzestrzeniającą się pandemią, jedną ze strategii firm funkcjonujących w branży motoryzacyjnej jest produkowanie coraz droższych samochodów (zwłaszcza w segmencie SUV), co pozwala na wyższy zysk jednostkowy. To z kolei jest wypadkową kilku czynników, takich jak między innymi ostre unijne regulacje dotyczące emisji spalin i przejścia na elektromobilność. Warto podkreślić, iż spełnienie wyśrubowanych norm i uruchomienie produkcji aut z napędem elektrycznym i zastosowaniu wysoce innowacyjnego know-how jest bardzo kapitałochłonne. Zatem pandemia COVID-19 może przyczynić się do odłożenia tego typu inwestycji w czasie, głównie za sprawą braku wystarczających środków finansowych. Ponadto 
konsekwencją sytuacji kryzysowej związanej z pandemią jest ograniczenie wydatków na dobra wyższego rzędu potencjalnych konsumentów.

Pewnego rodzaju zachętą dla poszczególnych producentów pojazdów silnikowych i części do nich, jak wskazują, byłoby uproszczenie przepisów dotyczących pomocy państwa oraz zapewnienie ulg podatkowych, gwarancji inwestycyjnych, pożyczek niskooprocentowanych i innych środków wsparcia dla producentów, a jeśli sytuacja będzie się przedłużać, rozszerzanie wachlarza pomocy. Wszystko to jest niezbędne, aby zapewnić przetrwanie wielu podmiotom dotkniętym kryzysem. Kufelová oraz Raková przeprowadziły analizę wpływu epidemii COVID-19 na słowacką branżę motoryzacyjną, w której wykazały znaczący wpływ zaprzestania produkcji w branży motoryzacyjnej, również będącej filarem gospodarki, na wielkość wypracowanego PKB w Republice Słowackiej, podobnie jak ma to miejsce w Polsce. Autorki zauważyły, iż z punktu widzenia przyszłego rozwoju słowackiej branży motoryzacyjnej szczególnie ważne jest podjęcie działań, które usprawnią ekonomicznie administrację publiczną, stworzą korzystne warunki dla działalności podmiotów gospodarczych na Słowacji i jednocześnie zwiększą poziom gotowości na sytuacje kryzysowe w przyszłości. Do takich środków zaradczych można zaliczyć obniżkę podatków, oszczędności w administracji publicznej, a ponadto należy stworzyć elastyczne warunki zatrudnienia na rynku pracy. Fundusze państwowe powinny natomiast skoncentrować się na wspieraniu innowacyjności, co pozwoli uzyskać przewagę konkurencyjną na unijnym rynku, podobne rozwiązania powinny zostać przyjęte również w celu rozwoju dalszego rozwoju polskiej gospodarki (Kufelová, Raková, 2020).

Kolejną niezwykle istotną rzeczą, jaką uwzględniło większość przedstawicieli firm produkcyjnych z branży motoryzacyjnej, jest utrzymanie przepływu surowców i komponentów do produkcji części samochodowych w celu zachowania ciągłości łańcucha dostaw, a dotyczy to zarówno eksportu, jak i importu towarów. Ważnym skutkiem wpływu epidemii COVID-19 na branżę motoryzacyjną, według analityków, będzie cena modeli samochodów. Możemy zaobserwować dwie dostępne opcje: po pierwsze, ministerstwa poszczególnych krajów wspomogą wielkie koncerny samochodowe, a restrykcyjne normy spalin nie zostaną wprowadzone. Dzięki temu ceny aut mogą pozostać stałe lub lekko się obniżyć, by zachęcić klientów do kupna. W przypadku braku dofinansowania, pochodzącego z pomocy publicznej, może nastąpić sytuacja, iż wprowadzone normy dotyczące emisji $\mathrm{CO}_{2}$ będą nie do spełnienia. Wówczas z pewnością należy się liczyć z poważnymi podwyżkami cen samochodów. Ponadto, jak słusznie stwierdzono w ostatnim podsumowaniu „New Frontiers of the Automobile Industry” pod redakcją Covarrubiasa i Ramíreza Pereza, branża motoryzacyjna obecnie znajduje się $\mathrm{w}$ fazie transformacji, ciągłego przejścia spowodowanego przenoszeniem marketingu, centrów projektowych i produkcyjnych do gospodarek wschodzących. Następuje wielkie przekształcenie związane ze zmianami technologicznymi, takimi jak elektryfikacja pojazdów mechanicznych, czy wdrażanie Przemysłu 4.0, co więcej, wprowadzane są nowe modele biznesowe, takie jak car sharing, a zarazem nakładane są na przedsiębiorstwa funkcjonujące $\mathrm{w}$ branży nowe obostrzenia regulacyjne związane $\mathrm{z}$ celami klimatycznymi. To wszystko powoduje, że następuje przesunięcie produkcji z tradycyjnych i dojrzałych centrów produkcyjnych tzw. triad w kierunku krajów o niższych kosztach wytwarzania. Przyczynia się do swego rodzaju eksperymentowania z nowymi systemami mobilności, takimi jak pojazdy elektryczne, autonomiczne, co dodatkowo powoduje, iż wszelkie załamania w branży m.in. spowodowanie pandemią COVID-19 
dodatkowo oddziałują na zmiany siły i położenia geograficznego zachodzące w branży, umacniając bądź osłabiając pozycje poszczególnych gospodarek. Warto podkreślić, jak autorzy słusznie zauważyli, iż w obecnych czasach kluczową rolę odgrywa polityka publiczna, bowiem wspiera działania w zakresie innowacji w państwach znajdujących się na czele rankingu liderów innowacji, co w rezultacie przyczyni się do znacznie szybszego wyjścia z kryzysu ekonomicznego państw, w których wskaźnik innowacyjności branży motoryzacyjnej jest stosunkowo wyższy (Covarrubias, Ramírez Perez, 2020).

Pandemia powoduje zaburzenia działalności wielu gałęzi gospodarki i wiele firm, nawet przy wsparciu państwa będzie musiało obniżać koszty oraz redukować zatrudnienie, co w efekcie może powodować zwolnienia grupowe. Pracodawcy, by w jak najwyższym stopniu chronić istniejące miejsca pracy, powinni mieć większą swobodę w decydowaniu, których pracowników dotyczy przestój lub obniżony wymiar czasu pracy, jak również we wprowadzaniu innych elastycznych zasad dotyczących wykonywania pracy przez pracowników.

Trudno wyrokować, jak będzie kształtowała się sytuacja w okresie popandemicznym. Jak słusznie zauważają Radić, Radić i Stevanović, że w stosunku do poprzedniego kryzysu z lat 2008-2010 obecna sytuacja jest bezprecedensowa. Zerwane łańcuchy dostaw, zaprzestanie produkcji, zamykanie fabryk, zwolnienia oraz spadające zainteresowanie i popyt klientów na samochody to okoliczności, które prowadzą przemysł motoryzacyjny do głębszej recesji, a czas jej trwania lub możliwości powrotu do stanu sprzed pandemii są nieznane (Radić, Radić, Stevanović, 2020).

Pewną nadzieję budzą liczne projekty koncernów motoryzacyjnych związane z rozwojem elektromobilności. W 2021 roku do produkcji wdrożonych zostanie wiele aut elektrycznych, w co zaangażowani są także dostawcy zlokalizowani w Polsce. Warto również podkreślić, iż przyszłość branży motoryzacyjnej w Polsce w znacznym stopniu zależeć będzie od poprawy sytuacji na rynkach motoryzacyjnych krajów Unii Europejskiej - głównych rynkach zbytu dla polskich fabryk. Badanie zmian zachodzących w przemyśle motoryzacyjnym za sprawą szerzącej się pandemii COVID-19 ograniczone jest dostępnością danych - większość zestawień i raportów zawiera dane dla pierwszych trzech kwartałów 2020 roku, zatem kompletną analizę, bardziej obrazową będzie można przeprowadzić już po tym, jak w raportach będą uwzględnione roczne dane. Warto również podkreślić, iż perspektywa przyszłych badań naukowych może być rozszerzona o analizy przeprowadzone we wszystkich krajach Unii Europejskiej, a także mogą być uwzględnione kolejne zmienne, takie jak liczba zamówień, poziom zatrudnienia czy wpływ na poziom innowacyjności branży.

W perspektywie długoterminowej można przewidywać, iż pozytywnym aspektem dla polskich zakładów jest fakt, że produkują one miejskie i kompaktowe samochody oraz części do ich produkcji, natomiast w czasie spowolnienia gospodarczego to właśnie na tego rodzaju pojazdy istnieje większy popyt. W 2009 roku, czyli w okresie światowego kryzysu gospodarczego, według statystyk wyraźnie zwiększył się udział samochodów miejskich w sprzedaży w całej Europie (o 6,2\%), co docelowo może być traktowane jako szansa na wyjście z kryzysu ekonomicznego dla polskiej branży motoryzacyjnej. Nie należy jednak sądzić, że załamanie w Polsce nie będzie głębsze i bardziej długotrwałe, niż w wyżej rozwiniętych krajach. Może być ono mniej odczuwalne, za co odpowiadać może fakt dotyczący znaczącego spadku wartości złotego, co zwiększy konkurencyjność Polski na rynkach zagranicznych i przyciągnie nowe bezpośrednie inwestycje zagraniczne. W publikacji Pavlínka (2017), dotyczącej sytuacji przemysłu 
motoryzacyjnego w Słowacji, można bowiem dostrzec, jak istotne są implikacje sprzężeń strukturalnych typu platformy montażowej dla długoterminowego regionalnego rozwoju gospodarczego na zintegrowanych peryferiach, ponieważ jakość i ilość powiązań bezpośrednich inwestycji zagranicznych jest kluczowa dla przewagi konkurencyjnej, jaka może być wypracowana za sprawą dyfuzji technologii i wiedzy w regionach przyjmujących BIZ. W perspektywie krótkoterminowej skoncentrowanej na rynku wewnętrznym należy zauważyć, iż pandemia bardzo szybko dotarła do Polski wpływając na zmniejszenie popytu wewnętrznego. Natomiast skutkiem pandemii oddziałującym długoterminowo jest fakt, że pandemia wpływa również na pozostałe rynki europejskie, które są ściśle powiązane z polskim rynkiem motoryzacyjnym. Ponad 70\% krajowej wartości dodanej z produkcji pojazdów samochodowych, naczep i przyczep oraz części absorbowane jest za granicą, głównie w Niemczech, Wielkiej Brytanii i Włoszech, co dodatkowo sprawia, że wszelkie reperkusje związane z nagłym załamaniem gospodarczym wpływają również na polską branżę motoryzacyjną.

\section{Literatura \\ References}

ACEA. (2020a). Elastyczność produkcji jako czynnik wspierający bezpieczeństwo biznesu. Brussels: eZ Publish.

ACEA. (2020b). Produkcja pojazdów w Polsce i w Europie. Brussels: eZ Publish.

Baldwin, R., Tomiura, E. (2020). Thinking ahead about the trade impact of Covid-19. Pobrano $\mathrm{z}$ https://repository.graduateinstitute.ch/record/298220

Covarrubias, V.A., Ramírez Perez, S.M. (2020). New Frontiers of the Automobile Industry Exploring Geographies, Technology, and Institutional Challenges. Londyn: Palgrave Studies of Internationalization in Emerging Markets.

Domański, B., Guzik, R., Gwosdz, K. (2005). The new spatial organization of automotive industry in Poland in the context of its changing role in Europe. Studia Regionalia, 15, 153-171.

Domański, B., Guzik, R., Gwosdz, K., Dej, M. (2013). The crisis and beyond. The dynamics and restructuring of automotive industry in Poland. International Journal of Automotive Technology and Management, 13(2).

Dorocki, S. (2010). Współczesne procesy internacjonalizacji produkcji i delokalizacji przemysłu samochodowego Francji. Prace Komisji Geografii Przemysłu Polskiego Towarzystwa Geograficznego, 16, 125-136.

Engel, K. (2008). Future Innovation Paradigms-Potential, Opportunities and Threats. Londyn.

Ernst and Young. (2020). Wpływ COVID-19 na branżę motoryzacyjnq w Polsce. Pobrano z https:// www.ey.com/pl_pl/covid-19/wplyw-covid19-na-branze-motoryzacyjna-w-polsce

Exact System. (2020). MotoBarometr 2019-2020. Pobrano z https://motobarometr.pl/

Gliński, C. (2018). Wpływ bezpośrednich inwestycji zagranicznych na przemysł motoryzacyjny w Polsce. Biuletyn Informacyjny, 2, ITS, Warszawa, 11-20.

Gorzelak, G. (red.). Domański, B., Dutkiewicz, P., Jałowiecki, B. (2009). Geografia polskiego kryzysu. Kryzys peryferii czy peryferia kryzysu? Warszawa: Regional Studies Association - Sekcja Polska.

Gudanowska, A., Toermaenen, A., Alonso, E. (2018). What competencies are needed in production industry. Engineering Management in Production and Services, 10(1), 65-74.

GUS. (2019). Produkcja wyrobów przemysłowych - nakłady i wyniki przemysłu. Warszawa.

GUS. (2020). Produkcja wyrobów przemysłowych zwiq̨zanych z zapobieganiem rozprzestrzeniania się COVID-19 w październiku 2020 r. Warszawa.

Gwosdz, K., Micek, G. (2010). Spatial agglomerations in the Polish automotive industry. Przeglad Geograficzny, 82(2).

Herrigel, G. (2010). Manufacturing Possibilities. New York: Oxford University Press.

Ivanov, D. (2020). Global Production Networks, Foreign Direct Investment, and Supplier Linkages in the Integrated Peripheries of the Automotive Industry. Economic Geography, 94, 141-165. 
Jürgens, U., Krzywdzinski, M. (2009). Work models in the Central Eastern European car industry: towards the high road? Industrial Relations Journal, 40(6), 471-490.

Kłosińska, O., Dedo-Oledzka, K. (2008). Zwycięskie strategie łańcuchów dostaw. Harvard Business Review Polska, 3, 133.

KPMG. (2019). Stan branży motoryzacyjnej oraz jej rola w polskiej gospodarce. Pobrano z https://www.pzpm.org.pl/Publikacje/Raporty/Stan-branzy-motoryzacyjnej-oraz-jej-rola-wpolskiej-gospodarce3 (dostęp 21.12.2020).

KPMG. (2020). Branża motoryzacyjna w Polsce - Raport kwartalny Q3 PZPM i KPMG, Pobrano z https://www.pzpm.org.pl/Publikacje/Raporty

Kudłak, R., Kisiała, W., Gadziński, J., Dyba, W., Kołsut, B., Stryjakiewicz, T. (2017). Społecznoekonomiczne i przestrzenne uwarunkowania popytu na nowe samochody w Polsce. Studia Regionalne i Lokalne, 2, 119-139.

Kufelová, I., Raková, M. (2020). Impact of the Covid-19 Pandemic on the Automotive Industry in Slovakia and Selected Countries. Current Problems of the Corporate Sector 2020. 17th International Scientific Conference. Paris: Édition Diffusion Presse Sciences.

Łuka, P., Woźniak, H. (2012). Współczesne problemy zarządzania logistyką w przemyśle motoryzacyjnym (cz. 2). Logistyka, 2.

Misztalewski, K., Daniluk, A. (2018). Konkurencyjność w branży motoryzacyjnej na przykładzie rynku sprzedaży samochodów w Polsce. Akademia Zarządzania. Politechnika Białostocka, 2(2), 68-85.

Mutrynowski, T. (2015). Rynek samochodów osobowych w Polsce. Kwartalnik Nauk o Przedsiębiorstwie, 1, 91-101.

Nakamura, H., Managi, S. (2020). Airport risk of importation and exportation of the COVID-19 pandemic. Transport Policy Journal, 96.

Pavlínek, P., Domański, B., Guzik, R. (2009). Industrial upgrading through foreign direct investment in Central European automotive manufacturing. European Urban and Regional Studies, 16(1).

Pavlínek, P., Ženka, J. (2011). Upgrading in the automotive industry. Firm-level evidence from Central Europe. Journal of Economic Geography, 3, 559-586.

Pavlínek, P. (2012). The impact of the 2008-2009 crisis on the automotive industry. Global trends and firm-level effects in Central Europe. European Urban and Regional Studies, 16, 1-21.

Pavlínek, P. (2017). Global Production Networks, Foreign Direct Investment, and Supplier Linkages in the Integrated Peripheries of the Automotive Industry. Economic Geography, 94.

Pucher, J. (1995). The road to ruin? Impacts of economic shock therapy on urban transport in Poland. Transport Policy, 2(1), 5-13.

PZPM. (2020). Automotive industry report 2020/2021, Pobrano z https://www.pzpm.org.pl/en/ Automotive-market/Reports/PZPM-Automotive-Industry-Report-2020-2021

Radić, N., Radić V., Stevanović, M. (2020). Economic Impact of the Coronavirus Pandemic on the Automobile Industry. Oditor, 6, 55-88.

Stowarzyszenie Dystrybutorów i Producentów Części Motoryzacyjnych. (2019). Branża motoryzacyjna 2019. Pobrano z http://sdcm.pl/2019/03/05/pozycja-polski-na-motoryzacyjnej-mapie-europy-czyli-co-przyniesie-przyszlosc-w-motoryzacji/ (dostęp 21.01.2021).

Stowarzyszenie Dystrybutorów i Producentów Części Motoryzacyjnych. (2020). Raport wobec zagrożenia branży motoryzacyjnej spowodowanym pandemiq koronawirusa. Pobrano z https://staleo.pl/z-kraju-i-ze-swiata/aktualnosci/4037/raport-sdcm-branza-motoryzacyjna-w-erze-covid-19

Sztaudynger, J.M. (2002). Wpływ bezpośrednich inwestycji zagranicznych na polski przemysł samochodowy. Gospodarka Narodowa, 5-6.

Wiedermann, K. (2007). Regionalne efekty mnożnikowe rozwoju przemysłu motoryzacyjnego w aktywizacji gospodarczej województwa śląskiego. Przedsiębiorczość-Edukacja, 3, 23-35.

Wójtowicz, M., Rachwał, T. (2014). Globalization and New Centers of Automotive Manufacturing - the Case of Brazil, Mexico, and Central Europe. Prace Komisji Geografii Przemysłu Polskiego Towarzystwa Geograficznego, 25, 81-107.

Karolina Stojczew, mgr, doktorantka, Uniwersytet Ekonomiczny we Wrocławiu, Katedra Gospodarki Regionalnej. Jej zainteresowania naukowe koncentrują się na problematyce rozwoju innowacyjności, badań i rozwoju w przemyśle motoryzacyjnym, ze szczególnym uwzględnieniem Polski na tle innych państw Unii 
Europejskiej. Zainteresowania naukowe pokrywają się z pracą zawodową w jednej z firm funkcjonujących w branży motoryzacyjnej.

Karolina Stojczew, MA, PhD student at the Wroclaw University of Economics and Business in the Department of Regional Economy. Her academic interests focus on the issues of the development of innovation, research and development in the automotive industry, with particular emphasis on Poland compared to other European Union countries. Research interests coincide with professional work in one of the operating companies in the automotive industry.

\section{ORCID: https://orcid.org/0000-0002-8442-7911}

\section{Adres/address:}

Uniwersytet Ekonomiczny we Wrocławiu

Katedra Gospodarki Regionalnej

ul. Komandorska 118/120

53-345 Wrocław, Polska

e-mail: karolina.stojczew@ue.wroc.pl 